\title{
Том \\ The types of visible scientists
}

\section{Arko Olesk}

Abstract

Keywords

DOI
We lack a good framework to characterize media-related adaptations of researchers. This paper explores Estonian scientists visible in the media to propose five dimensions to characterize the degree of mediatization of a researcher, and describes two basic types of visible scientists.

Representatives of one type ('adapters to media logic') are able to explain the project simply and engagingly in the media, while those of the second type ('adopters of media logic') proactively create media interactions and manage them to achieve strategic aims. The results show how individual actors translate communication objectives into media practices, explaining variabilities in scientists' media presence.

Professionalism, professional development and training in science communication; Science and media; Science communication: theory and models

https://doi.org/10.22323/2.20020206

Submitted: 15th June 2020

Accepted: 23rd December 2020

Published: 22nd March 2021

When Rae Goodell put forward the concept of 'visible scientists' in the 1970s, she had in mind "scientists... visible primarily neither for discoveries, for popularizing, nor for leading the scientific community, but for activities in the tumultuous world of politics and controversy" [Goodell, 1977, p. 6]. Scientists like Carl Sagan or Linus Pauling "used their prominence to draw public attention to their era's pressing science policy issues" [Fahy, 2017, p. 1020] which, according to Goodell, represented a new trend in the relationship between science and the media. The high profile of certain scientists was achieved, Goodell argued, because they were "aggressively taking advantage of the new communications media" [Goodell, 1977, p. 6] and had developed a "remarkable cooperation" and "sophistication" in dealing with the press [Goodell, 1977, pp. 8-9]. In short, "they were uniquely attuned to the needs of the mass media" [Fahy, 2017, p. 1020].

Goodell's observation of the mechanism that produces visibility for scientists has not lost its relevance in the following decades. We have observed media's increasing interest for science stories and controversies within it [Schäfer, 2011], and a strong policy push, both on national and international levels for more and better science communication [Weingart and Joubert, 2019; Trench et al., 2014], 
leading to a general expectation that every scientist should actively participate "in the visibility of science by engaging in communication with its diverse publics" [Rödder, 2012, pp. 158-159]. We have seen new forms of public visibility such as celebrity scientists [Fahy, 2015] or social media activity [Ke, Ahn and Sugimoto, 2017; Liang et al., 2014; Shema, Bar-Ilan and Thelwall, 2012].

In Goodell's times, media visibility was often seen as a controversial in the scientific community, perceived as harmful to the credibility and productivity of the researchers [Goodell, 1977]. While the concerns of visibility's possible eroding impact to science are still raised [e.g. Weingart, 2012], achieving and sustaining visibility has now become a common goal, especially for research organizations [Scheu and Olesk, 2018; Kohring et al., 2013].

The change, both in the case of Goodell's policy-oriented visible scientists and the recent expansion of visibility-producing activities, can partly be attributed to the realization that public visibility is a valuable resource. Changes in science, that also kickstarted the science communication movement, have added a number of motives that visibility, especially via media, is supposed to achieve: besides influencing policy, visibility is perceived to helpful for increasing public support and trust for science, influence citizen behaviour, increase public understanding of science; but also bring funding and students [Gregory and Miller, 2000; Kappel and Holmen, 2019; Ruão, Correia Neves and Magalhães, 2015; Weingart and Joubert, 2019].

As a consequence, we have seen that activities within the practice of science communication are increasingly oriented towards achieving media visibility and supported by, for example, media training workshops for researchers or employing an increasing number of communication specialists at research institutions. From a critical perspective, the situation is understood as problematic from two perspectives: first, the activities designed to promote and persuade dominate over activities seeking to educate and inform [Peters, Brossard, de Cheveigné, Dunwoody, Heinrichs et al., 2009; Weingart and Joubert, 2019]. Second, orientation towards media leads to adaptations with media's operating logic, reducing the autonomy of science [Peters, Brossard, de Cheveigné, Dunwoody, Heinrichs et al., 2009; Weingart, 2012].

Other authors [e.g. Besley, 2020; Roberson, 2020], however, argue that we need organizational communication activities and to use the principles of public relations theory and practice to be more effective in science communication, also with the educational aims. This tension calls for a deeper look into the communication motives of scientists and how these reflect in the individual communication practices, including media interactions.

Some authors [Horst, 2013; Väliverronen, 2001] have already mapped the different roles that scientists take in the media, ranging from explainer of their work to lobbying for a particular goal. It is reasonable to think that various goals require different (media) skills to be successfully achieved. Therefore, the signs of diversification of the scientists' position in the science-media relationship invites an updated look at visible scientists and seek for a better understanding of the characteristics of their visibility. Foremost, this paper aims to offer a list of indicators which could be used to evaluate the mediatization pattern of a scientist, 
and, thereby, provide a possible tool to detect and analyse variabilities of motives and adaptations in scientists' visibility-driven interactions with the media.

The framework for this analysis is provided by the mediatization approach, a theory that investigates the interdependencies of various social systems (such as science) with media. Its focus on describing societal changes that are initiated by the permeation of media to all areas of modern life makes it helpful in discussing the changes that are taking place in science. The focus on mediatization on the individual level enables to investigate the changes of practices of scientists due to their interaction with mass media channels, and relate this to their media skills and motives of communication.

Visibility is understood in this paper as frequent presence in journalistic mass media, therefore a situation that is a result of mediatization processes or contributes to the mediatization of involved scientists.

This paper uses interviews made with visible scientists in Estonia to answer the following research questions: 1) What indicators can be used to describe the mediatization characteristics of individual scientists? and 2) What types of visible scientists can be constructed using these indicators?

\section{Indicators of mediatization}

Mediatization (also medialization) is a theoretical framework discussing the influences of media and communications in other social and cultural domains such as politics or science [Hepp, Hjarvard and Lundby, 2015]. The growing impact of media technologies and mass media systems in our societies creates a dependence [Hjarvard, 2013] of culture and society on the media and its formats, leading to transformation of societal institutions [Hjarvard, 2013; Marcinkowski, 2014; Strömbäck, 2008]. The institutional perspective of mediatization describes how "media logic", i.e. the form and formats of communication [Altheide, 2013] is becoming accommodated [Schulz, 2004] into the processes of various societal institutions in response to the perceived role of media in the society, and links these to the long-term cultural and social change that follows such mediated communication [Lundby, 2014].

There have been few attempts to develop a systematic set of indicators to evaluate mediatization. This is mostly due to the dominance of the macro- or meso-level approach in mediatization studies dealing with processes that are not easily operationalizable. Helpful starting points include Jesper Strömbäck's [2008] phases of mediatization. He describes the final phases of mediatization as situations where (political) actors start adapting to media logic, and, finally, the actors adopting media logic to the extent that it becomes internalized to their institutional processes [Strömbäck, 2008].

A more detailed framework to operationalize mediatization was offered by Scheu, Volpers et al. [2014] They investigated how decision makers in research organizations perceive the role of media in research policy and defined three structural levels on which changes take place: constellations of actors, expectations, and interpretations. In detail, mediatization in the constellation of actors takes 
place when the position and influences of actors change due to mass media. Changes in structures of expectations might include transformation in formal and informal norms, regulations, organizational structures etc. Finally, adaptations in structures of interpretations include changes in organizations' or individuals' objectives, motives, cognitive and evaluative orientations [Scheu, Volpers et al., 2014, p. 712].

Studies using this framework [Scheu and Olesk, 2018; Scheu, Volpers et al., 2014; Scheu, 2019] have shown that research institutions perceive media to have an increasingly important role in the research policy setting, leading to accommodations in university structure (e.g. expanding public relations offices) and practices (e.g. providing media training for staff) to achieve more public visibility or respond to general mediatization processes in the society. The science decision makers who favour offensive strategies of mediatization to increase their influence among stakeholders also report more extensive structural adaptations within their organizations [Scheu, 2019].

While the institutional factors can contribute to the visibility of individual scientists, they can also work against it, for example as part of a mechanism to protect the values of science [Scheu, 2019]. The tensions that visible scientists perceive about their role expectations have been discussed, among others, by Goodell [1977] and by Rödder [2012]. Therefore, individual factors are relevant in achieving visibility and we require a framework to analyse the factors that lead to mediatization on the micro-level.

One such framework - the model of "mental mediatization" - is proposed [Marcinkowski, 2014], taking politics as an example. According to this model, the experience of the omnipresence of the media triggers changes in the thinking, communicating, and acting of the individuals: politicians experience at first-hand what powers of influence the media can exercise. This experience, coupled with frequent contact with journalists, the persuasions of media advisers and their own extensive media consumption, leads to the development of ideas about how media function [pp. 17-18]. Here, considering the recent intensification of the science-media relationship, the concept of "mental mediatization" allows us to understand (and investigate) mediatization as a phenomenon that is manifesting itself via the perceived understandings of media logic by individuals, and the influence of these perceptions on their actions [Olesk, 2019b].

Already Goodell noted some changes that we now can label as signs of mediatization. As explained by Fahy [2017, p. 1020], Goodell's visible scientists were "controversial and articulate, had a colourful image and had a hot topic that made their work relevant to social concerns... The scientists crafted in part a public image that conformed to these characteristics in order to make themselves more likely to be selected and given prominence by media figures".

In a meta-analysis Peters [2013] shows that most scientists consider visibility in the media important and responding to journalists a professional duty. Several studies on mediatization of science [Olesk, 2019b; Peters, 2013; Rödder, 2009; Rödder and Schäfer, 2010; Scheu, Volpers et al., 2014] have given indications that scientific actors have a perception of a distinct media logic. Other proposed hallmarks, summarized by Rödder and Schäfer [2010], Schäfer [2014] and Rödder [2009] 
include promoting research results through press conferences, sometimes even before the official scientific publication, and the proactive use of promotional metaphors such as the 'catastrophe' discourse in climate research. However, as Schäfer [2014] admits, these indicators are often based on extreme or non-routine cases.

The frameworks presented in this section indicate that while the concept of media logic is at the core of mediatization, it leads to specific kinds of adaptions, practices and changes in various social fields and on different levels. Therefore, the need for specific qualitative indicators to describe the mediatization of scientists leads us to the first research question: What indicators can be used to describe the mediatization characteristics of individual scientists?

The approach taken to formulate the indicators is guided by the work of Schweitzer [2012]. Working of mediatization of politics, she presents a list of six empirical indicators. These include, among others "the extent to which parties or candidates adopt a journalistic news style to address the public", "the amount by which political messages are triggered by mediatized or staged events in comparison to genuine events", "the extent to which parties' communication revolves around their top candidates, their personalities, and private lives at the expense of other political actors" and "the degree to which parties concentrate in their messages on conflict and criticism rather than on positive self-promotion" [Schweitzer, 2012, p. 285]. This list serves as a model not so much in terms of the proposed indicators themselves (since these represent elements quite specific to politics) but for the way it breaks mediatization down into elements that are possible to evaluate. Combined, these indicators allow characterization of the extent and nature of mediatization of parties or individual candidates.

\section{Scientists in the media - motives and roles}

The role of institutional actors such as universities, conferences and journals has become more important [Peters, Brossard, de Cheveigné, Dunwoody, Kallfass et al., 2008; Peters, 2013] and their press releases have considerable influence on media content [Granado, 2011; Weitkamp and Eidsvaag, 2014]. Still, despite increasing mediation between scientist and media, it is the motivation and contribution of the scientists that shapes the fundamental characteristics of science communication.

Studies that have investigated the motives of scientists to engage in public communication reveal a mix of motives, combining objectives related to personal, institutional and public benefits. Often mentioned personal motives include enjoyment and/or a sense of duty or responsibility, increasing the public's interest in, understanding of and enthusiasm for science, and gaining trust [Cerrato et al., 2018; Entradas et al., 2019; Gascoigne and Metcalfe, 1997; Loroño-Leturiondo and Davies, 2018; Martín-Sempere, Garzón-García and Rey-Rocha, 2008; Peters, Brossard, de Cheveigné, Dunwoody, Kallfass et al., 2008; Rose, Markowitz and Brossard, 2020; Sanz Merino and Tarhuni Navarro, 2019]. The works of Besley and colleagues [Besley, Dudo and Yuan, 2018; Besley, O'Hara and Dudo, 2019; Dudo and Besley, 2016] have analysed the predictors of prioritizing between objectives and various tactics used to accomplish them. 
At the same time, a number of scholars, starting from Goodell, emphasize the political dimension in science communication, for example in the form of engaging in societal debates and agenda-building [Goodell, 1977; Nisbet and Markowitz, 2015; Scheufele, 2014]. The need to differentiate between the educational and political functions of science communication - both for analytical clarity and practical reasons - was recently highlighted by Weingart and Joubert [2019] although they associate the political motives almost exclusively with institutional actors.

Massimiano Bucchi [1996] has pointed out that in certain situations, usually connected to scientific controversies, scientists start to address the public directly by skipping the usual stages of scientific communication. These situations create a new modality in science communication that is associated with different objectives and tactics compared to the traditional dissemination pathways. Together, these observations illustrate that when conducting analysis on scientists' presence in media, we need to consider the choices made by the actors in terms of objectives and tactics within a specific context - in short, analyse what roles scientists perform in media. Currently, there is no framework that manages to extensively conceptualize the possible roles but a few papers suggest possible role sets that scientists perform in media.

Analysing the media coverage of forest damage in Finland, Väliverronen [2001] defines five roles for scientists as experts in public discourse: populariser, interpreter, adviser/advocate, promoter/manager and critic. A populariser presents new research results, interpreter discusses new phenomena and problems, adviser/advocate makes policy claims or comments on them, promoter/manager seeks to legitimize science (e.g. by justifying the use of public funds), and critic comments on research results [Väliverronen, 2001]. Researchers interviewed by Väliverronen see themselves usually combining two or three roles, the majority preferring the role of interpreter. The roles of populariser, advocate and critic were next, more or less equally popular [Väliverronen, 2001].

In her interviews with Danish scientists, Horst [2013] identified three different ideal roles that scientists can take when they represent science: Expert, Research Manager, and Guardian of Science. In the first role, scientists primarily represent a scientific field or discipline and communicate scientific facts. In the second role, they explicitly refer to the research organization and make efforts to portray their research organization in a favourable light. In the third role, they represent the institution of science and focus the communication activities on improving the public's understanding of science [Horst, 2013].

The two presented role sets have both their own virtues for analysing scientists in the media. What both show us, moreover, is that there are distinct roles for scientists, each implying "particular notions of quality, audience, motivation, and learning in science communication" [Horst, 2013, p. 758]. Taken from there, we can hypothesize that each role might also require somewhat different adaptations or set of adaptations to media logic, therefore creating a characteristic pattern of mediatization. Once we have identified qualitative indicators to describe the mediatization of scientists, we can start looking at what are the different mediatization patterns among visible scientists and correlate them with perceived roles. This provides us the second research question: What types of visible scientists can be constructed using these indicators? 
This paper uses a two-step approach to develop and corroborate the indicators. Both steps employ qualitative semi-structured interviews with researchers: indicators were inductively developed based on the data from the first group; the second group served for corroboration of the indicators and provided data to construct the types of visible scientists.

Following the frameworks presented in the theoretical section, we can understand individual-level mediatization as a combination of media-related mental concepts, attitudes and practices. By evaluating these aspects and their interrelations, as reflected by the respondents, we are able characterize someone's mediatization. This consideration guided the selection of semi-structured interviews as the research method, since this method allows comparison on the participants' responses "while simultaneously seeking to fully understand their unique experiences" [Barlow, 2010, p. 497].

The first group $(n=8)$ consists of members of the group that built and launched the satellite ESTCube-1. This was the first Estonian satellite, it was devised and built by a group of graduate and postgraduate students of Estonian universities under the supervision or a senior researcher [Olesk and Noorma, 2021]. The project achieved high visibility in Estonia, releasing 30 press releases and generating 160 original media items during the course of the project between 2008 in 2015 [Olesk, 2019a]. The nature of media coverage and data gathered with interviews about the media attitudes and practices of the team members support the conclusion that the group became mediatized during the project [Olesk, 2019b; Olesk, 2019a]. For a detailed description of the satellite project and the sample, please see [Olesk and Noorma, 2021; Olesk, 2019b].

The interviews with the group members aimed to understand the nature of their media interactions and the process of mediatization. The interviews focussed on the following topics: description and evaluation of their media interactions during the project, perception of media logic, process of learning the media skills and perception of media's impact on the project. For developing the indicators, I performed coding of the interviews in a two-step process: initial or open coding to broadly identify differences in the media-related attitudes and practices of the respondents, followed by selective or focused coding [Charmaz and Belgrave, 2012], resulting in five indicators (presented in Table 2).

Since ESTCube-1 was not a standard research project, a second group was compiled to corroborate whether the indicators produce meaningful explanations also in another sample. The sample consisted of Estonian scientists $(n=8)$ who can be considered publicly visible. The group included three researchers who have been awarded the Person of the Year recognition by the Postimees newspaper and three recent recipients of the award Friend of Science Journalists, awarded by the Estonian Association of Science Journalists. ${ }^{1}$ Estonian universities were approached to find out whether they have statistics about their most media-visible researchers - such data existed in one university and the top researcher was included in the sample. In addition, some respondents were selected because of their position: presidents of the Estonian Academy of Sciences and Estonian Young Academy of Sciences. Both organizations have recently made efforts to be publicly

\footnotetext{
${ }^{1}$ The supervisor of the ESTCube-1 team, interviewed in the first group, has also received both the Person of the Year recognition and the Friend of Science Journalists award.
} 
Table 1. Interviewed visible scientists.

\begin{tabular}{|c|c|c|c|}
\hline $\begin{array}{l}\text { Interview } \\
\text { no }\end{array}$ & Research field & Position & Recognition/visible project \\
\hline 1 & Engineering & Professor & Friend of Science Journalists \\
\hline 2 & Bird ecology & $\begin{array}{l}\text { Researcher/department } \\
\text { communication specialist }\end{array}$ & $\begin{array}{l}\text { Most productive author of the } \\
\text { university }\end{array}$ \\
\hline 3 & Genetics & Senior researcher & Estonian Biobank \\
\hline 4 & $\begin{array}{l}\text { Molecular } \\
\text { biology }\end{array}$ & Professor & Friend of Science Journalists \\
\hline 5 & $\begin{array}{l}\text { Conservation } \\
\text { biology }\end{array}$ & Senior researcher & Person of the Year \\
\hline 6 & Genetics & Professor & $\begin{array}{l}\text { Person of the Year, Estonian } \\
\text { Biobank }\end{array}$ \\
\hline 7 & Physics & Senior Researcher & Young Academy of Sciences \\
\hline 8 & $\begin{array}{l}\text { Physical } \\
\text { oceanography }\end{array}$ & Professor & $\begin{array}{l}\text { Estonian Academy of } \\
\text { Sciences, Friend of Science } \\
\text { Journalists, Person of the Year }\end{array}$ \\
\hline
\end{tabular}

visible. Finally, the sample included two leading representatives from the Estonian Biobank. The project has a long history of public engagement and, at the time of the interview, was conducting a national campaign to recruit 100,000 gene donors. Some respondents featured simultaneously in several categories (see Table 1). The gender balance in the second group was 6:2 in favour of men, while the first group was all-male. Studies on gender balance in Estonian media [e.g. Org, 2016; Pärnapuu et al., 2017; Pilvre, 2012] indicate that this ratio reflects the general visibility of women experts in the media discourse. Among the nine recipients of the Friend of Science Journalists award, six have been male, whereas only two women have been individually received the Person of the Year title, awarded annually since 1997.

The interviews with the visible scientists were structured according to the five dimensions identified with the previous group but to allow the possibility of new indicators being found, the interviews also included open-ended questions [Roulston, 2008] about the respondents' perspective about and experiences with media. The author analysed the interview transcripts deductively based on the five dimensions and did an inductive analysis to explore possible additional important codes.

Interviews with ESTCube-1 team members ranged from 24 to 95 minutes, lasting 54 minutes on average. Interviews with visible scientists ranged from 49 to 71 minutes, lasting 58 minutes on average. The interviews were held in Estonian (except for one in English), fully transcribed, either by the author or by a service provider, and manually coded by the author. Presented quotes were translated into English after being selected to the article.

Results

Interviewed members of the ESTCube- 1 team all shared an understanding that media visibility is relevant for the project. At the same time, despite the rather small number of respondents, the group turned out to be internally diverse enough 
Table 2. Five dimensions that provide indicators for evaluating the mediatization of scientists.

\begin{tabular}{|l|l|}
\hline Dimension & Indicator description \\
\hline $\begin{array}{l}\text { Communication as a } \\
\text { responsibility }\end{array}$ & $\begin{array}{l}\text { The extent to which the scientists see public communication } \\
\text { as part of their professional responsibility }\end{array}$ \\
\hline $\begin{array}{l}\text { Awareness of media } \\
\text { logic }\end{array}$ & $\begin{array}{l}\text { The extent to which the scientists express awareness of } \\
\text { media logic and feel confident in using journalistic news } \\
\text { style to address the public }\end{array}$ \\
\hline $\begin{array}{l}\text { Mastering media } \\
\text { logic }\end{array}$ & $\begin{array}{l}\text { The extent to which the scientists feel confident in mastering } \\
\text { media logic and using it to trigger media coverage (via } \\
\text { press conferences, press releases, directly contacting } \\
\text { journalists) or introduce angles relevant for them }\end{array}$ \\
\hline $\begin{array}{l}\text { Purposeful use of } \\
\text { media }\end{array}$ & $\begin{array}{l}\text { The extent to which the scientists see media as a tool for } \\
\text { achieving their scientific or non-scientific aims }\end{array}$ \\
\hline $\begin{array}{l}\text { Institutionalization } \\
\text { of communication } \\
\text { activities }\end{array}$ & $\begin{array}{l}\text { The extent to which the communication activities in the } \\
\text { research group/organization have been institutionalized } \\
\text { within the professional activities of the scientist }\end{array}$ \\
\hline
\end{tabular}

in their media-related attitudes and practices to allow the development of an analytical framework.

The coding resulted in identification of five dimensions that provide indicators for evaluating the mediatization of scientists (see Table 2). The framework combines insights from mental mediatization framework [Marcinkowski, 2014] about the role of scientists' perception of media logic and media impact in shaping their practices, from the framework of structural change [Scheu, Volpers et al., 2014] about the role of norms and cognitive evaluations in guiding the adaptations to media logic, and from the phases of mediatization [Strömbäck, 2008] about the level of intensity regarding adaptations to media logic. The general design of the framework is based on Schweitzer [2012].

The first dimension - the extent to which the scientists see public communication as part of their professional responsibility - covers, for example, the readiness to incorporate public communication into their professional activities. In this group, some respondents were more ready to devote their resources for communication, others saw it as secondary in comparison with research.

Perceiving and using media logic can be described via expressed attitudes and practices such as, among others, knowledge about how to behave in an interview, understanding that journalists work on tight deadlines and make major simplifications, thinking in terms of target groups and messages, issuing press releases and initiating media coverage. Two separate indicators are proposed for media logic to distinguish between different types of involvement in media content production. One of them has researchers in a responsive position, i.e. deals with how well they are able to handle interactions with journalists. This does not only include the ability to respond to questions and explain the science but also interactions and routines during the whole process, from preparation to reflecting on the outcome.

For example, preparation for the media interactions is described as an active process that enables better control of the communication. The regular routines 
include asking the journalist for background information about the upcoming interview (length, channel, format etc.), requesting the questions upfront by e-mail, and requesting to have a look at the final draft of the article (in case of print media).

The other indicator evaluates the proactive capabilities of the researchers, e.g. activities that are related to promoting their work or efforts of agenda-setting. In this dimension, the researchers have a stronger agency and can become equal - or even more powerful - actors than the journalists. Proactivity also means initiating media coverage and choosing the device to provide most visibility. ESTCube-1 project supervisor explains his strategy:

\begin{abstract}
"I have learned that a press release is not the best device... [When preparing to release some news] I would make agreements with newspapers that are ready to put the news on their front page or write a longer article... I would make separate deals, give them material so by the moment that we issue a press release, certain channels are professionally prepared and ready to gain a certain advantage. I will help them to gain this advantage. They will have an exclusive material. For others, it is nice if they pick up the press release but there is no harm if they don't." (Group 1, interview 1)
\end{abstract}

The fourth dimension discusses the perceived benefits of visibility and researchers' motives for media interactions. ESTCube- 1 team members gave various responses to the question what aims do they feel media coverage helps them to achieve. These range from specific benefits to the project to wider societal aims: introducing the project to the general public, popularizing STEM subjects (science, technology, engineering and maths), increasing public support for science, ensuring political support for space sciences or attracting students to the project and to the university.

The final indicator deals with the extent of institutionalization of public communication. All systematic media activities of the ESTCube team, ranging from managing web page and posting to social media to writing press releases remained voluntary. In retrospect, some team members expressed opinion that communication would have benefitted if the communication duties had been clearly assigned to some team members or a special person engaged with these tasks.

For the ESTCube-1 group, we can conclude that the five proposed indicators reflect functional differences in the respondents' relationship with the media and help to evaluate the level of mediatization. The next step was to test whether the developed indicators perform similarly when applied on a wider, more diverse group of visible researchers.

Interviews with the second group of respondents, indeed, confirmed that the indicators enable seeing and describing variability in the mediatization patterns of (visible) scientists. No need for adjusting or adding indicators was identified. The analysis process leading to the patterns is exemplified on Figure 1 (based on the indicator "Purposeful use of media" and using illustrative quotes from respondents in the second group, visible scientists). For each indicator, the responses of interviewees of the second group were evaluated, compared to each other and situated on the scale that reflects the extent of mediatization, either concerning their mental concepts about media or self-described adaptations to media logic. 


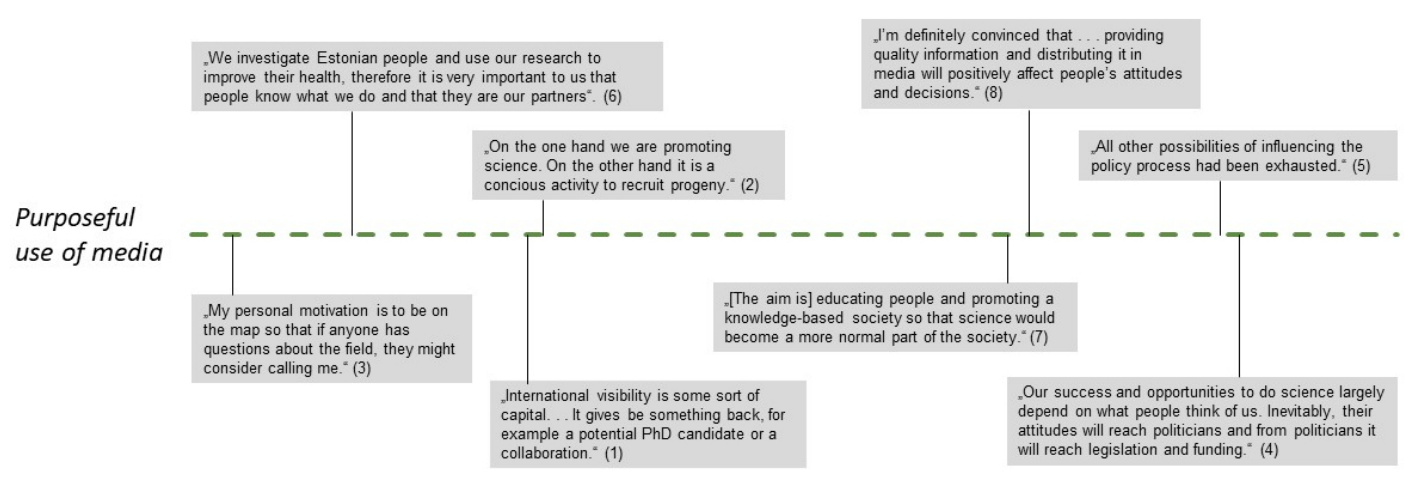

Figure 1. Example of indicator analysis in the process of creating patterns of mediatization. Quotes are from the second group of interviewees (visible scientists).

Table 3. Basic typology of mediatized scientists.

\begin{tabular}{|l|l|l|}
\hline Dimension & Adapters to media logic & Adopters of media logic \\
\hline $\begin{array}{l}\text { Communication as } \\
\text { a responsibility }\end{array}$ & $\begin{array}{l}\text { See it as important but } \\
\text { secondary to their scientific } \\
\text { work. }\end{array}$ & $\begin{array}{l}\text { See it equally important to } \\
\text { their scientific work. }\end{array}$ \\
\hline $\begin{array}{l}\text { Awareness of } \\
\text { media logic }\end{array}$ & $\begin{array}{l}\text { Are able to explain their work } \\
\text { in simple terms and feel } \\
\text { confident giving interviews. } \\
\text { Criticize journalists' routines. }\end{array}$ & $\begin{array}{l}\text { Are able to understand and } \\
\text { accept the journalists' work } \\
\text { logic, and express themselves } \\
\text { in journalistic news style. }\end{array}$ \\
\hline $\begin{array}{l}\text { Mastering media } \\
\text { logic }\end{array}$ & $\begin{array}{l}\text { Are not familiar with news } \\
\text { production practices; write an } \\
\text { occasional press release; } \\
\text { otherwise do not initiate } \\
\text { media coverage. }\end{array}$ & $\begin{array}{l}\text { Contact journalists proactively } \\
\text { and manage to 'sell' stories } \\
\text { and angles to them. }\end{array}$ \\
\hline $\begin{array}{l}\text { Purposeful use of } \\
\text { media }\end{array}$ & $\begin{array}{l}\text { See media coverage as } \\
\text { benefitting the current project } \\
\text { or result (getting attention, } \\
\text { increasing awareness about } \\
\text { issue etc.). }\end{array}$ & $\begin{array}{l}\text { Have more strategic aims } \\
\text { (wider benefits to science, } \\
\text { economy etc.) and think in } \\
\text { terms of target groups and } \\
\text { messages. }\end{array}$ \\
\hline $\begin{array}{l}\text { Institutionalization } \\
\text { of communication } \\
\text { activities }\end{array}$ & $\begin{array}{l}\text { Perform communication } \\
\text { activities on ad hoc basis. }\end{array}$ & $\begin{array}{l}\text { Conduct communication } \\
\text { activities systematically and } \\
\text { follow a strategic plan, } \\
\text { integrating public } \\
\text { communication into the } \\
\text { professional activities of the } \\
\text { scientist. }\end{array}$ \\
\hline
\end{tabular}

While each respondent had a distinct pattern of mediatization and did not fall neatly into the identified types, two clusters emerged. Roughly, these were located at the - if described in a very simplified way - low- and high-level ends of the dimensions. Based on the clusters, two basic types of mediatized scientists could be developed - labelled adapters to media logic and adopters of media logic. Table 3 provides an overview of the characteristics of both types.

The two types both represent scientists who might be considered good science communicators by the public. The types, however, reflect varying extent of media-related adaptations of the scientist, associated with different objectives that 
researchers assign to their communication activities and ways in which the communication is executed. The adapters know how to handle interview situations and are able to explain their work in lay-person's terms. At the same time, they see the aim of the media interactions mostly as explaining their research and place great emphasis on the correct representation of their work. They prefer to have communication professionals involved with the project allowing them to concentrate on their research.

The second type is labelled adopters because they have internalized media handling skills and uses these consciously to manage media attention. The adopters acknowledge and explicitly express the instrumental nature of their communication activities: interaction with media is not only seen as promoting their own project by also as a device to gain public support, inspire young people or convince policy makers. What characterizes interaction with media in this discourse is not as much focus on explaining scientific facts or results but promoting a more general agenda. Hence, the main concern is not about media getting the facts right but the senders getting their message across. The discourse displays itself also in the language of the interviewees: they use terms like "target group" and "message" which are characteristic to the field of public relations. This reveals that the interviewees perceive media as a powerful actor in the society, capable of influencing other actors.

The placement of the respondents in types rather seems to correlate with their pathway to visibility, i.e. the usual mechanism by which media presence is created. For example, the respondents who can be described as adapters, described that the interaction is usually initiated by the journalist, calling the researcher and asking to comment on something in their expert field. Therefore, much of the visibility can be considered media-driven. These respondents see their role in the media mostly as 'popularizers' or 'interpreters' (to use Väliverronen's terms).

The respondents who displayed higher level of mediatization ('adopters') were more likely to be leading an institution or major project, or be public champions of a specific topic. While their visibility also included the media-driven component, they described significant either personal or institutional efforts to gain media visibility and have adopted media practices that support their strategic objectives (see quote below). Therefore, we can describe their visibility as position-driven or strategic goal driven.

\footnotetext{
"[Short] interviews are a very bad journalistic format for a scientist. I use them more or less consciously to create interest for a longer contact. So I give this 1-minute interview but my real goal could be that we get together [with the journalist] and talk about the topic more in-depth... I have had my reservations about journalistic interest for my person. So far, I have almost always managed to make [person interviews] work for [introducing the scientific] topic." (Group 2, interview 5)
}

We also see that, depending on the situation, scientists can switch between the types, adopting a proactive role for one project or topic and remaining responsive for another. The motivations behind such visibility management behaviour present a relevant topic for further studies. 
Stig Hjarvard [2014, p. 202] has defined mediatization as "institutionalization of new patterns of social interaction". Several frameworks have been proposed for the identification and characterization of these patterns. However, none of these seems to work well in the micro-level context of mediatization of scientists, prompting me to propose a new one. Evaluating the level of mediatization on each of these five functionally different dimensions gives us the mediatization pattern of the individual researcher. The individual patterns lead the way for defining basic types of visible scientists.

In the context of public communication of science and technology, the patterns of mediatization and types of visible scientists are most relevant for understanding and investigating variabilities in scientists' media presence. They link the why? and the how? of science communication: mediatization patterns and visibility types help to see how the individual actors translate communication objectives and aims into media practices. These results help to explain the roles that both Horst [2013] and Väliverronen [2001] have found in their media analysis, support the move towards creating a more complete catalogue of roles that scientists fulfil in media, and invite for a discussion about the most relevant roles and skills required to achieve the various objectives of science communication.

Such discussion is relevant because many more pathways to visibility have become possible after Goodell first wrote about visible scientists. The understanding of these pathways to visibility and the factors that shape them, from journalistic practices to scientists' motives and skills, should be a necessary component in all current discussions related to science in media.

At the same time, there are still tensions in the scientific community about what constitutes acceptable visibility [Rödder, 2012], whether all motives support the mission of science communication [Weingart and Joubert, 2019] or whether and how a close relationship with the media can threaten the credibility or core values of science [Weingart, 2012]. The indicators of mediatization and the visibility types can be useful tools both for the critical approach for evaluating the positions that scientists have in the media arena and uncovering micro-level processes that lead to institutional change, and for the practice of science communication by suggesting possible visibility managing practices that provide the greatest benefits for the public and science as an institution.

Media-related learning outcomes feature in many science communication training programs [Baram-Tsabari and Lewenstein, 2017]. A better understanding of the attitudes, skills and practices related to individual-level mediatization can also help to design and evaluate the impact of science communication training activities. The two basic types of mediatized (or visible) scientists proposed in this paper is a distinction such programs should especially take into account.

Given the small sample and the focus on scientists who are already widely visible, this paper remains an exploratory investigation on the variabilities in visibility. To confirm the validity of the framework, studies in other countries would be required, or studies that include a greater variability of researchers in terms of their visibility and media experience. Investigating the pathways to visibility is a promising avenue for further research. 
Altheide, D. L. (2013). 'Media logic, social control, and fear'. Communication Theory 23 (3), pp. 223-238. https: //doi.org/10.1111/comt.12017.

Baram-Tsabari, A. and Lewenstein, B. V. (2017). 'Science communication training: what are we trying to teach?' International Journal of Science Education, Part B 7 (3), pp. 285-300. https://doi.org/10.1080/21548455.2017.1303756.

Barlow, C. A. (2010). 'Interviews'. In: Encyclopedia of Case Study Research. Ed. by A. J. Mills, G. Durepos and E. Wiebe. Thousand Oaks, CA, U.S.A.: SAGE Publications, Inc., pp. 496-499. https://doi.org/10.4135/9781412957397.n182.

Besley, J. C. (2020). 'Five thoughts about improving science communication as an organizational activity'. Journal of Communication Management 24 (3), pp. 155-161. https://doi .org/10.1108/JCOM-03-2020-0022.

Besley, J. C., Dudo, A. and Yuan, S. (2018). 'Scientists' views about communication objectives'. Public Understanding of Science 27 (6), pp. 708-730. https://doi.org/10.1177/0963662517728478.

Besley, J. C., O'Hara, K. and Dudo, A. (2019). 'Strategic science communication as planned behavior: understanding scientists' willingness to choose specific tactics'. PLOS ONE 14 (10), e0224039. https://doi.org/10.1371/journal. pone. 0224039.

Bucchi, M. (1996). 'When scientists turn to the public: alternative routes in science communication'. Public Understanding of Science 5 (4), pp. 375-394. https://doi.org/10.1088/0963-6625/5/4/005.

Cerrato, S., Daelli, V., Pertot, H. and Puccioni, O. (2018). 'The public-engaged scientists: motivations, enablers and barriers'. Research for All 2 (2), pp. 313-322. https://doi.org/10.18546/RFA.02.2.09.

Charmaz, K. and Belgrave, L. (2012). 'Qualitative interviewing and grounded theory analysis'. In: The SAGE handbook of interview research: the complexity of the craft. Ed. by J. Gubrium, J. Holstein, A. Marvasti and K. McKinney. Thousand Oaks, CA, U.S.A.: SAGE Publications, Inc., pp. 347-366. https://doi.org/10.4135/9781452218403.

Dudo, A. and Besley, J. C. (2016). 'Scientists' prioritization of communication objectives for public engagement'. PLoS ONE 11 (2), e0148867, pp. 1-18. https://doi.org/10.1371/journal.pone.0148867.

Entradas, M., Marcelino, J., Bauer, M. W. and Lewenstein, B. (2019). 'Public communication by climate scientists: what, with whom and why?' Climatic Change 154 (1-2), pp. 69-85. https://doi .org/10.1007/s10584-019-02414-9.

Fahy, D. (2015). The new celebrity scientists: out of the lab and into the limelight. Lanham, MD, U.S.A.: Rowman \& Littlefield Publishers.

- (2017). 'Historical moments in public understanding of science: 1977, The Visible Scientists identifies a new scientist for the mass media age'. Public Understanding of Science 26 (8), pp. 1019-1024. https://doi.org/10.1177/0963662517732909.

Gascoigne, T. H. and Metcalfe, J. (1997). 'Incentives and impediments to scientists communicating through the media'. Science Communication 18 (3), pp. 265-282. https://doi.org/10.1177/1075547097018003005.

Goodell, R. (1977). 'The Visible Scientists'. The Sciences 17 (1), pp. 6-9. https://doi.org/10.1002/j.2326-1951.1977.tb01494.x.

Granado, A. (2011). 'Slaves to journals, serfs to the web: the use of the Internet in newsgathering among European science journalists'. Journalism 12 (7), pp. 794-813. https://doi.org/10.1177/1464884911412702. 
Gregory, J. and Miller, S. (2000). Science in public: communication, culture, and credibility. New York, NY, U.S.A.: Hachette Book Group.

Hepp, A., Hjarvard, S. and Lundby, K. (2015). 'Mediatization: theorizing the interplay between media, culture and society'. Media, Culture $\mathcal{E}$ Society 37 (2), pp. 314-324. https://doi .org/10.1177/0163443715573835.

Hjarvard, S. (2013). The mediatization of culture and society. London, U.K. and New York, NY, U.S.A.: Routledge.

- (2014). 'Mediatization and cultural and social change: an institutional perspective'. In: Mediatization of communication: handbooks of communication science. Ed. by K. Lundby. Boston, MA, U.S.A.: De Gruyter Mouton, pp. 199-226. https://doi .org/10.1515/9783110272215.199.

Horst, M. (2013). 'A field of expertise, the organization, or science itself? Scientists' perception of representing research in public communication'. Science Communication 35 (6), pp. 758-779. https://doi.org/10.1177/1075547013487513.

Kappel, K. and Holmen, S. J. (2019). 'Why science communication, and does it work? A taxonomy of science communication aims and a survey of the empirical evidence'. Frontiers in Communication 4, 55. https://doi.org/10.3389/f comm.2019.00055.

Ke, Q., Ahn, Y.-Y. and Sugimoto, C. R. (2017). 'A systematic identification and analysis of scientists on Twitter'. PLoS ONE 12 (4), e0175368. https://doi.org/10.1371/journal. pone.0175368.

Kohring, M., Marcinkowski, F., Lindner, C. and Karis, S. (2013). 'Media orientation of German university decision makers and the executive influence of public relations'. Public Relations Review 39 (3), pp. 171-177. https://doi.org/10.1016/j.pubrev.2013.01.002.

Liang, X., Su, L. Y.-F., Yeo, S. K., Scheufele, D. A., Brossard, D., Xenos, M., Nealey, P. and Corley, E. A. (2014). 'Building buzz: (scientists) communicating science in new media environments'. Journalism \& Mass Communication Quarterly 91 (4), pp. 772-791. https://doi.org/10.1177/1077699014550092.

Loroño-Leturiondo, M. and Davies, S. R. (2018). 'Responsibility and science communication: scientists' experiences of and perspectives on public communication activities'. Journal of Responsible Innovation 5 (2), pp. 170-185. https://doi.org/10.1080/23299460.2018.1434739.

Lundby, K. (2014). 'Mediatization of communication'. In: Mediatization of communication. Ed. by K. Lundby. Berlin, Germany and Boston, MA, U.S.A.: De Gruyter Mouton, pp. 3-38.

Marcinkowski, F. (2014). 'Mediatisation of politics: reflections on the state of the concept'. Javnost - The Public 21 (2), pp. 5-22. https://doi.org/10.1080/13183222.2014.11009142.

Martín-Sempere, M. J., Garzón-García, B. and Rey-Rocha, J. (2008). 'Scientists' motivation to communicate science and technology to the public: surveying participants at the Madrid Science Fair'. Public Understanding of Science 17 (3), pp. 349-367. https://doi.org/10.1177/0963662506067660.

Nisbet, M. C. and Markowitz, E. M. (2015). 'Expertise in an age of polarization: evaluating scientists' political awareness and communication behaviors'. The ANNALS of the American Academy of Political and Social Science 658 (1), pp. 136-154. https://doi .org/10.1177/0002716214559699.

Olesk, A. (2019a). 'Media coverage of a strongly mediatized research project: the case of the Estonian satellite ESTCube-1'. Mediální Studia 13 (1), pp. 7-27. 
Olesk, A. (2019b). 'Mediatization of a research group: the Estonian student satellite ESTCube-1'. Science Communication 41 (2), pp. 196-221. https://doi.org/10.1177/1075547018824102.

Olesk, A. and Noorma, M. (2021). 'The engagement activities of ESTCube-1: how Estonia built and fell in love with a tiny satellite'. In: Space science and public engagement: 21st century perspectives and opportunities. Ed. by A. Kaminski. In press. Amsterdam, The Netherlands: Elsevier.

Org, K. (2016). 'Saatekülaliste ekspertiisitüübid telesaates "Vabariigi kodanikud"'. Tartu, Estonia: University of Tartu. URL: https://dspace.ut.ee/bitstream/ha ndle/10062/52034/org_kadri_ba_2016.pdf? sequence=1\&isAllowed=y.

Pärnapuu, P., Päären, M.-L., Pruudel, K., Prants, K. and Pulk, M. (3rd March 2017). 'Sooline lõhe Eesti Ekspressi persoonilugudes'. Sirp.

URL: https://www.sirp.ee/s1-artiklid/c21-teadus/sooline-lohe-eesti-e kspressi-persoonilugudes/.

Peters, H. P. (2013). 'Gap between science and media revisited: scientists as public communicators'. Proceedings of the National Academy of Sciences 110 (Supplement 3), pp. 14102-14109. https://doi.org/10.1073/pnas.1212745110.

Peters, H. P., Brossard, D., de Cheveigné, S., Dunwoody, S., Heinrichs, H., Jung, A., Kallfass, M., Miller, S., Petersen, I., Tsuchida, S., Cain, A. and Paquez, A.-S. (2009). 'Medialisierung der Wissenschaft und ihre Relevanz für das Verhältnis zur Politik'. In: Medienorientierung biomedizinischer Forscher im internationalen Vergleich. Die Schnittstelle von Wissenschaft \& Journalismus und ihre politische Relevanz. Ed. by H. P. Peters. Jülich, Germany: Forschungszentrum Jülich, pp. 9-43.

Peters, H. P., Brossard, D., de Cheveigné, S., Dunwoody, S., Kallfass, M., Miller, S. and Tsuchida, S. (2008). 'Science-media interface: it's time to reconsider'. Science Communication 30 (2), pp. 266-276. https://doi.org/10.1177/1075547008324809.

Pilvre, B. (2012). 'Gender aspects of media tabloidization process in Estonia'. Media Transformations 8, pp. 102-124. https://doi.org/10.7220/2029-865X.08.06.

Roberson, T. (2020). 'On social change, agency and public interest: what can science communication learn from public relations?' JCOM 19 (02), Y01. https://doi.org/10.22323/2.19020401.

Rödder, S. (2009). 'Reassessing the concept of a medialization of science: a story from the "book of life"'. Public Understanding of Science 18 (4), pp. 452-463. https://doi.org/10.1177/0963662507081168.

- (2012). 'The ambivalence of visible scientists'. In: The sciences' media connection - Public communication and its repercussions. Ed. by S. Rödder, M. Franzen and P. Weingart. Vol. 28. Sociology of the Sciences Yearbook. Dordrecht, The Netherlands: Springer, pp. 155-177. https://doi.org/10.1007/978-94-007-2085-5_8.

Rödder, S. and Schäfer, M. S. (2010). 'Repercussion and resistance. An empirical study on the interrelation between science and mass media'. Communications 35 (3), pp. 249-267. https://doi.org/10.1515/comm. 2010.014.

Rose, K. M., Markowitz, E. M. and Brossard, D. (2020). 'Scientists' incentives and attitudes toward public communication'. Proceedings of the National Academy of Sciences 117 (3), pp. 1274-1276. https://doi .org/10.1073/pnas . 1916740117.

Roulston, K. J. (2008). 'Open-ended question'. In: The SAGE Encyclopedia of Qualitative Research Methods. Ed. by L. M. Given. Thousand Oaks, CA, U.S.A.: SAGE Publications, Inc., pp. 582-583. 
Ruão, T., Correia Neves, I. and Magalhães, R. (2015). 'Science and strategic communication: how can universities attract high school students?'

URL: https://repositorium. sdum.uminho.pt/bitstream/1822/65148/1/2015 _Ruao_Neves_Magalhaes_Science-and-strategic-communication.pdf.

Sanz Merino, N. and Tarhuni Navarro, D. H. (2019). 'Attitudes and perceptions of Conacyt researchers towards public communication of science and technology'. Public Understanding of Science 28 (1), pp. 85-100. https://doi.org/10.1177/0963662518781466.

Schäfer, M. S. (2011). 'Sources, characteristics and effects of mass media communication on science: a review of the literature, current trends and areas for future research'. Sociology Compass 5 (6), pp. 399-412. https://doi.org/10.1111/j.1751-9020.2011.00373.x.

- (2014). 'The media in the labs, and the labs in the media: what we know about the mediatization of science'. In: Mediatization of communication. Ed. by K. Lundby. Berlin, Germany and Boston, MA, U.S.A.: De Gruyter Mouton, pp. 571-594. https://doi.org/10.1515/9783110272215.571.

Scheu, A. M. (2019). 'Between offensive and defensive mediatization. An exploration of mediatization strategies of German science-policy stakeholders'. JCOM 18 (03), A08. https://doi.org/10.22323/2.18030208.

Scheu, A. M. and Olesk, A. (2018). 'National contextual influences on mediatization: the comparison of science decision makers in Estonia and Germany'. Science Communication 40 (3), pp. 366-392. https://doi.org/10.1177/1075547018766917.

Scheu, A. M., Volpers, A.-M., Summ, A. and Blöbaum, B. (2014). 'Medialization of research policy: anticipation of and adaptation to journalistic logic'. Science Communication 36 (6), pp. 706-734. https://doi.org/10.1177/1075547014552727.

Scheufele, D. A. (2014). 'Science communication as political communication'. Proceedings of the National Academy of Sciences 111 (Supplement 4), pp. 13585-13592. https://doi.org/10.1073/pnas.1317516111.

Schulz, W. (2004). 'Reconstructing mediatization as an analytical concept'. European Journal of Communication 19 (1), pp. 87-101. https://doi.org/10.1177/0267323104040696.

Schweitzer, E. J. (2012). 'The mediatization of e-campaigning: evidence from German party websites in state, national, and European parliamentary elections 2002-2009'. Journal of Computer-Mediated Communication 17 (3), pp. 283-302. https://doi.org/10.1111/j.1083-6101.2012.01577.x.

Shema, H., Bar-Ilan, J. and Thelwall, M. (2012). 'Research blogs and the discussion of scholarly information'. PLoS ONE 7 (5), e35869. https://doi.org/10.1371/journal. pone.0035869.

Strömbäck, J. (2008). 'Four phases of mediatization: an analysis of the mediatization of politics'. The International Journal of Press/Politics 13 (3), pp. 228-246. https://doi.org/10.1177/1940161208319097.

Trench, B., Bucchi, M., Amin, L., Cakmakci, G., Falade, B., Olesk, A. and Polino, C. (2014). 'Global spread of science communication: institutions and practices across continents'. In: Routledge Handbook of Public Communication of Science and Technology. Ed. by M. Bucchi and B. Trench. 2nd ed. London, U.K. and New York, U.S.A.: Routledge, pp. 214-230.

https://doi.org/10.4324/9780203483794. 
Väliverronen, E. (2001). 'Popularisers, interpreters, advocates, managers and critics: framing science and scientists in the media'. Nordicom Review 22 (2), pp. 39-47. https://doi.org/10.1515/nor-2017-0353.

Weingart, P. (2012). 'The lure of the mass media and its repercussion on science'. In: The sciences' media connection - Public communication and its repercussions. Ed. by S. Rödder, M. Franzen and P. Weingart. Vol. 28. Sociology of the Sciences Yearbook. Dordrecht, The Netherlands: Springer, pp. 17-32. https://doi.org/10.1007/978-94-007-2085-5_2.

Weingart, P. and Joubert, M. (2019). 'The conflation of motives of science communication - causes, consequences, remedies'. JCOM 18 (03), Y01. https://doi.org/10.22323/2.18030401.

Weitkamp, E. and Eidsvaag, T. (2014). 'Agenda building in media coverage of food research'. Journalism Practice 8 (6), pp. 871-886. https://doi.org/10.1080/17512786.2013.865966.

Author

Arko Olesk is a Lecturer in Science Communication in Tallinn University, Estonia, where his Ph.D. project focusses on the mediatization of scientists. Previously, he worked as a science journalist in Estonia's leading publications and received an MSc in science communication from Imperial College London. He regularly trains Ph.D. students and researchers on science communication.

E-mail: arko.olesk@tlu.ee.

How to cite

Olesk, A. (2021). 'The types of visible scientists'. JCOM 20 (02), A06. https://doi.org/10.22323/2.20020206. 